\title{
TIPE-2 suppresses growth and aggressiveness of hepatocellular carcinoma cells through downregulation of the phosphoinositide 3-kinase/AKT signaling pathway
}

\author{
LIN WANG, CHEN CHEN, SHUZHI FENG and JIANLI TIAN
}

Department of Geriatrics, Tianjin Medical University General Hospital, Tianjin Geriatrics Institute, Tianjin 300052, P.R. China

Received November 11, 2016; Accepted December 14, 2017

DOI: $10.3892 / \mathrm{mmr} .2018 .8789$

\begin{abstract}
Rapid proliferation and migration are the main features of hepatocellular carcinoma (HCC) cells, which serve an essential role in carcinogenesis and are a hallmark of cancer therapy resistance. Previous studies have reported that tumor necrosis factor- $\alpha$-induced protein- 8 like-2 (TIPE-2) is involved in cancer initiation and the progression of HCC. The present study aimed to clarify the role of TIPE-2 in HCC carcinogenesis, growth and aggressiveness. The effects of TIPE-2 on HCC were determined using colony forming and cell cycle analyses. Cell apoptosis, and growth and aggressiveness of HCC cells, were investigated following TIPE-2 treatment. Treatment with TIPE-2 markedly suppressed HCC cell proliferation and increased the number of cells in $\mathrm{S}$ phase of the cell cycle. The results demonstrated that TIPE-2 significantly inhibited growth, migration and invasion of HCC cells via the downregulation of tumor metastasis-associated genes. Flow cytometric analysis indicated that TIPE-2 promoted apoptosis of HCC cells via regulation of apoptosis-associated gene transcription. In addition, TIPE-2 administration downregulated the expression of phosphoinositide 3-kinase (PI3K) and protein kinase B (AKT) in HCC cells. In addition, TIPE-2 selectively decreased neuroblastoma Ras viral oncogene and p27 expression in HCC cells. In vivo assays revealed that TIPE-2 significantly inhibited tumor growth and prolonged animal survival by promoting apoptosis of tumor cells. The results of the present study indicated that TIPE-2 acts as an inhibitor of HCC cell growth and aggressiveness, and promotes apoptosis, thus suggesting that TIPE-2 may inhibit the metastasis-associated PI3K/AKT signaling cascade and may arrest the tumor cell cycle. These findings provide
\end{abstract}

Correspondence to: Professor Jianli Tian, Department of Geriatrics, Tianjin Medical University General Hospital, Tianjin Geriatrics Institute, 154 Anshan Road, Heping, Tianjin 300052, P.R. China E-mail: tianjianlisuv@163.com

Key words: tumor necrosis factor- $\alpha$-induced protein- 8 like-2, hepatocellular carcinoma cells, apoptosis, metastasis, phosphoinositide 3-kinase/protein kinase B a potential molecular mechanism by which TIPE-2 promotes apoptosis of HCC cells.

\section{Introduction}

Hepatocellular carcinoma (HCC) is the second most common type of cancer, which is characterized by high morbidity and mortality rates, and accounts for $>90 \%$ of primary liver cancer cases $(1,2)$. A previous systematic review and meta-analysis indicated that HCC is associated with a high level of recurrence and has the second highest cancer-associated mortality rate worldwide, even following radiotherapy, chemotherapy and/or surgery $(3,4)$. At present, the available therapeutic strategies remain limited, particularly for patients with advanced HCC, which exhibit poor survival, according to a 5-year survival study (5-7). Previous studies have revealed that HCC is a genetically complex, multifactorial and heterogeneous tumor $(8,9)$. Therefore, various anticancer therapies that target different signaling pathways have been investigated for HCC therapy $(10,11)$.

The common clinical therapeutic strategies used to treat patients with cancer are currently surgery, chemotherapy and radiotherapy; however, efficacies remain poor and these treatments are associated with severe side effects during and after treatment (12). Numerous studies have focused on inhibition of the growth and aggressiveness of HCC, which may be associated with targeting proliferative signaling cascades $(13,14)$. The anti-invasive and anti-migratory effects of drugs contribute to limit regional migration and long-distance tumor metastasis of HCC cells by targeting cellular signaling pathways, which are involved in key signal transduction for various extracellular growth factors, and receptors of HCC cells $(15,16)$. In addition, the induction of human HCC cell apoptosis has been reported to stimulate anticancer activity via mitochondria-mediated activation of caspase- 9 and caspase-8-mediated proteolysis of BH3 interacting-domain death agonist, which may warrant further investigation for application in cancer treatment $(17,18)$.

Tumor necrosis factor (TNF)- $\alpha$-induced protein 8 -like- 2 (TIPE-2) is a negative regulator of innate and adaptive immunity $(19,20)$. TIPE-2 is downregulated in the majority of human cancer cells, including lung cancer, colon cancer, HCC and gastric cancer cells. Recently, Li et al (21) reported that TIPE-2 is a novel inflammatory regulator that may inhibit Toll-like receptor 4 (TLR4)-mediated development of colon 
cancer via TLR4-mediated upregulation of caspase-8; this may be considered a novel therapeutic target for clinical treatment. Zhao et al (22) also indicated that TIPE-2 is associated with the pathogenesis of gastric cancer and acts as a novel negative regulator of the immune system, which has been systematically investigated in murine and human cancer. Furthermore, a previous study demonstrated that regulating T-cell apoptosis by directly targeting the tumor suppressor gene TIPE-2 enhances the apoptotic sensitivity of tumor cells (23).

In the present study, TIPE-2-mediated phosphoinositide 3-kinase (PI3K)/protein kinas B (AKT) signaling was investigated in HCC cells. In addition, the inhibitory effects of TIPE-2 were analyzed on HCC cells; the results demonstrated that treatment with TIPE-2 significantly suppressed the growth and proliferation of HCC cells in vitro, and inhibited tumor formation in vivo. These findings suggested that TIPE-2 treatment may markedly inhibit tumor growth in HepG2-bearing mice, which further prolonged survival time for experimental mice. Mechanistic analysis indicated that TIPE-2 may induce apoptosis of HCC cells via the PI3K/AKT signaling pathway, which provides a potential therapeutic target for patients with HCC.

\section{Materials and methods}

Ethics statement. The present study was conducted in strict accordance with the recommendations of the Guide for the Care and Use of Laboratory Animals of Tianjin Medical University General Hospital (Tianjin, China). This study was approved by the Ethics Committee of Tianjin Medical University General Hospital. All surgery and euthanasia were performed under sodium pentobarbital anesthesia, and all efforts were made to minimize suffering.

Cell culture. HepG2 cells were purchased from the American Type Culture Collection (Manassas, VA, USA). HepG2 cells were cultured in Dulbecco's modified Eagle's medium (DMEM; Thermo Fisher Scientific, Inc., Waltham, MA, USA) supplemented with $10 \%$ heat-inactivated fetal bovine serum (FBS; Gibco; Thermo Fisher Scientific, Inc.) at $37^{\circ} \mathrm{C}$ in an atmosphere containing $5 \% \mathrm{CO}_{2}$.

Endogenous overexpression of PI3K or TIPE-2. HepG2 cells were cultured in 6-well plates until they reached $90 \%$ confluence and the medium was then removed. Sequences were cloned into vectors as previously described (24). Subsequently, HepG2 cells $\left(1 \times 10^{6}\right)$ were transfected with pedue12.4-PI3K $(100 \mathrm{nM})$, pedue12.4-TIPE-2 $(100 \mathrm{nM})$ or pedue12.4-vector (100 nM) using Lipofectamine ${ }^{\circledR} 2000$ (Invitrogen; Thermo Fisher Scientific, Inc.) for $48 \mathrm{~h}$ at $37^{\circ} \mathrm{C}$. Cells that exhibited stable PI3K or TIPE-2 overexpression were selected according to the dihydrofolate reductase/glutamine synthetase screening system (Invitrogen; Thermo Fisher Scientific, Inc.).

MTT cytotoxicity assays. HepG2 cells $\left(5 \times 10^{3}\right)$ were incubated with TIPE-2 (0.5-2.5 mg/ml; SinoGenoMax Co., Ltd., Beijing, China) in 96 -well plates for 24,48 and $72 \mathrm{~h}$ at $37^{\circ} \mathrm{C}$ in triplicate for each condition. In the control group, cells were treated with $2 \mathrm{ml}$ PBS instead of TIPE-2. Cell proliferation was determined using a MTT assay kit (Roche Diagnostics, Indianapolis, IN, USA). At each time point, $20 \mu \mathrm{l}$ MTT (5 mg/ml) in PBS was added to each well and the plate was incubated for $4 \mathrm{~h}$ at $37^{\circ} \mathrm{C}$. Most of the medium was then removed and $100 \mu \mathrm{l}$ dimethyl sulfoxide was added to the wells to solubilize the crystals. Optical density was measured using a Bio-Rad ELISA reader (Bio-Rad Laboratories, Inc., Hercules, CA, USA) at a wavelength of $450 \mathrm{~nm}$.

Colony formation assay. Culture medium supplemented with TIPE-2 $(2 \mathrm{mg} / \mathrm{ml})$ or with PBS was added to 6-well plates ( $2 \mathrm{ml}$ per well). HepG 2 cells $\left(1 \times 10^{5}\right.$ cells/well) were seeded into 6 -well plates. Medium was replaced at $48 \mathrm{~h}$ following cell attachment and subsequently every $48 \mathrm{~h}$. Cells were trypsinized (1\% trypsin), suspended in a $500 \mu 1$ volume of medium and a hemacytometer was used to determine the total number of cells per well on day 4 . The colony formation assays were performed in triplicate.

$m R N A$ expression analysis by reverse transcription-quantitative polymerase chain reaction ( $R T$-qPCR). Total cellular RNA was extracted from PI3K-overexpressed (PI3KOR), TIPE-2-overexpressed (TIPE-2OR) or control HepG2 cells using the RNeasy mini kit (Qiagen Sciences, Inc., Gaithersburg, MD, USA) according to the manufacturer's protocol. A total of $1 \mu \mathrm{g}$ total RNA was reverse transcribed into cDNA for $2 \mathrm{~h}$ at $42^{\circ} \mathrm{C}$. cDNA $(0.1 \mu \mathrm{g})$ was subjected to qPCR using an iQ SYBR-Green system (Bio-Rad Laboratories, Inc.). All primers were synthesized by Invitrogen (Thermo Fisher Scientific, Inc.) and the sequences used were as follows: PI3K forward, 5'-CTCATGCCAGGCACTGTGCTA-3' and reverse, 5'-GAATCAAGGCACACCTGTGGAA-3'; TIPE-2 forward, 5'-GGAACATCCAAGGCAAGACTG-3' and reverse, 5'-AGCACCTCACTGCTTGTCTCATC-3'; and $\beta$-actin forward, 5'-GACTACCTCATGAAGATCCTCACC-3' and reverse, 5'-TCTCCTTAATGTCACGCACGATT-3'. PCR was performed with the following thermocycling conditions: 45 amplification cycles of $96^{\circ} \mathrm{C}$ for $30 \mathrm{sec}$, annealing at $63^{\circ} \mathrm{C}$ for $20 \mathrm{sec}$, with touchdown to $54^{\circ} \mathrm{C}$ for $20 \mathrm{sec}$ and extension at $72^{\circ} \mathrm{C}$ for $5 \mathrm{~min}$. Results were expressed as a fold change by comparing levels of target mRNA expression to that of the reference gene using the $2^{-\Delta \Delta \mathrm{Cq}}$ method (25).

Western blot analysis. HepG2 cells were treated with TIPE-2 $(2.0 \mathrm{mg} / \mathrm{ml})$ for $24 \mathrm{~h}$ and were then homogenized with lysis buffer containing protease-inhibitor (cat. no. P3480; Sigma-Aldrich; Merck KGaA, Darmstadt, Germany). Protein concentration was measured with a bicinchoninic acid protein assay kit (Thermo Fisher Scientific, Inc.), protein (10 $\mu \mathrm{g} /$ lane) was separated by $12.5 \%$ SDS-PAGE and subsequently transferred to polyvinylidene fluoride membranes. Membranes were blocked with $5 \%$ milk for $2 \mathrm{~h}$ at $37^{\circ} \mathrm{C}$ prior to incubation with the following primary antibodies overnight at $4^{\circ} \mathrm{C}$ : PI3K (1:1,000; cat. no. ab191606), AKT $(1: 1,000$; cat. no. ab8805), neuroblastoma Ras viral oncogene (N-ras; 1:1,000; cat. no. ab206969), P27 (1:1,000; cat. no. ab191606), phosphorylated (p)AKT (1:1,000; cat. no. ab81283), binding immunoglobulin protein (BIP; 1:1,000; cat. no. ab108615), P53 (1:1,000; cat. no. ab1431), B-cell lymphoma 2 (Bcl-2; 1:1,000; cat. no. ab59348), cyclin D1 (1:1,000; cat. no. ab134175), cyclin-dependent kinase (CDK)1 (1:1,000; cat. no. ab131450), CDK2 (1:1,000; cat. no. ab32147), vimentin (VIM; 
1:1,000; cat. no. ab92547), collagen type I (CT-I; 1:1,000; cat. no. ab34710), Slug (1:1,000; cat. no. ab27568), c-Jun N-terminal kinase (JNK; 1:1,000; cat. no. ab124956), nuclear factor (NF)- $\mathrm{B}(1: 1,000$; cat. no. ab28849), nuclear factor (erythroid-derived 2)-like 2 (NRF2) (1:1,000; cat. no. ab62352), caspase-3 (1:1,000; cat. no. ab13847), caspase-8 (1:1,000; cat no. ab25901), glucose-regulated protein 78 (GRP78; 1:1,000; cat. no. ab21685), CCAAT-enhancer-binding protein homologous protein (CHOP; 1:1,000; cat. no. ab179823), eukaryotic initiation factor 2 (eIF2 $\alpha$; 1:1,000; cat. no. ab32713), peIF2 $\alpha$ (1:1,000; cat. no. ab214434) and $\beta$-actin (1:1,000; cat. no. ab827; Abcam, Shanghai, China) for $12 \mathrm{~h}$ at $4^{\circ} \mathrm{C}$. Membranes were then incubated with goat anti-rabbit horseradish peroxidase (HRP)-conjugated immunoglobulin G secondary antibody (1:2,000; cat. no. PV-6001; OriGene Technologies, Inc., Beijing, China) for $24 \mathrm{~h}$ at $4^{\circ} \mathrm{C}$. The blots were visualized using a chemiluminescence detection system (GE Healthcare, Chicago, IL, USA). Relative protein expression levels were calculated using Quantity-One software (version 3.0; Bio-Rad Laboratories, Inc.) and are presented as $n$-fold of $\beta$-actin expression levels.

Cell invasion and migration assays. HepG2 cells were treated with TIPE-2 $(2.0 \mathrm{mg} / \mathrm{ml})$ for $24 \mathrm{~h}$; untreated cells were used as a control. Migration and invasion assays of HepG2 cells were conducted in 6-well culture plates with chamber inserts (BD Biosciences, San Diego, CA, USA). For migration assays, $1 \times 10^{6} /$ well HepG2 cells were placed into the upper chamber with DMEM medium. The lower chamber contained DMEM medium with $0.1 \%$ FBS. For invasion assays, cells (1x10\%/well) were placed into the upper chamber with a Matrigel-coated insert. After $24 \mathrm{~h}$ culture at $37^{\circ} \mathrm{C}$, migratory and invasive cells were fixed with $1.4 \%$ paraformaldehyde for $30 \mathrm{~min}$ at $37^{\circ} \mathrm{C}$ and were stained for $30 \mathrm{~min}$ in $0.1 \%$ crystal violet solution in PBS. Migration and invasion of HepG2 cells was counted in at least three randomly selected fields per membrane using a light microscope (Olympus BX51; Olympus Corporation, Tokyo, Japan).

Flow cytometric analysis. HepG2 cells were cultured until they reached $85 \%$ confluence. Apoptotic rate was assessed following incubation with TIPE-2 $(2.0 \mathrm{mg} / \mathrm{ml})$ for $48 \mathrm{~h}$. Briefly, HepG2 cells were trypsinized and collected, the cells were then washed in cold PBS, adjusted to $1 \times 10^{8}$ cells $/ \mathrm{ml}$ with PBS, and labeled with Annexin V-fluorescein isothiocyanate (FITC) and propidium iodide (PI; Annexin V-FITC kit; BD Biosciences) for $2 \mathrm{~h}$ at $4^{\circ} \mathrm{C}$. Apoptotic rate was analyzed using FCS Express ${ }^{\mathrm{TM}}$ IVD software (version 4; De Novo Software, Glendale, CA, USA).

Viability assay. HepG2 cells were cultured in 6-well plates until they reached $85 \%$ confluence and the medium was then removed. Subsequently, HepG2 cells were washed three times and were incubated with DMEM supplemented with $10 \% \mathrm{FBS}$ and TIPE-2 $(2.0 \mathrm{mg} / \mathrm{ml})$ for $24 \mathrm{~h}$. Subsequently, the supernatant was removed and cells were incubated with Triton X-100 (1\%) for $30 \mathrm{~min}$. Lactate dehydrogenase activity in cell lysates was used to analyze cell viability using the Promega CytoTox 96 assay kit (Promega Corporation, Madison, WI, USA), according to the manufacturer's protocol.
Analysis of the cell cycle. To analyze the effects of TIPE-2 ( $2 \mathrm{mg} / \mathrm{ml}$ ) on the HepG2 cell cycle, flow cytometry was performed. HepG 2 cells in the exponential phase of growth were treated with TIPE-2 $(2 \mathrm{mg} / \mathrm{ml})$ for $48 \mathrm{~h}$ at $37^{\circ} \mathrm{C}$. Cells were subsequently washed with $\mathrm{PBS}$, trypsinized (1\% trypsin) for $5 \mathrm{~min}$ at $37^{\circ} \mathrm{C}$ and rinsed with PBS. Cells were fixed in $75 \%$ ice-cold ethanol for $15 \mathrm{~min}$ and washed with PBS three times. RNaseA (20 $\mu \mathrm{g} \mathrm{ml} / \mathrm{l}$; Fermentas; Thermo Fisher Scientific, Inc.) was added to fixed cells, which were subsequently stained with PI (20 $\mu \mathrm{g} \mathrm{ml} / \mathrm{l}$; Sigma-Aldrich; Merck KGaA) for $10 \mathrm{~min}$ at $37^{\circ} \mathrm{C}$. The percentage of cells in the G1, G2 and S phase were analyzed using a cell cycle analysis kit (cat. no. C34568; Invitrogen; Thermo Fisher Scientific, Inc.), a BD FACSCalibur flow cytometer (BD Biosciences) and FCS Express IVD software (version 4; De Novo Software).

Animal experiments. A total of 80 specific pathogen-free (SPF) female BALB/c nude mice (age, 6-8 weeks) were purchased from Harbin Veterinary Research Institute (Harbin, China). All mice were feed under pathogen-free conditions. Mice were maintained at $22-24^{\circ} \mathrm{C}$ in a $12 \mathrm{~h}$ light/dark cycle with ad libitum access to food and water. A total of $5 \times 10^{7}$ HepG2 cells were injected into the right flank of female BALB/c nude mice at a total volume of $200 \mu \mathrm{l}$. Tumor-bearing mice then underwent intratumoral injection with TIPE-2 $(6.0 \mathrm{mg} / \mathrm{ml})$ or PBS ( $\mathrm{n}=40 /$ group), once tumor diameters reached $5-8 \mathrm{~mm}$ on day 6 after tumor inoculation. The treatment was continued 15 times at intervals of every two days for a total of 30 days. Tumor diameters were recorded once every 2 days and tumor volume was calculated using the following formula: $0.52 \times$ smallest diameter ${ }^{2} \mathrm{x}$ largest diameter. Survival analysis was conducted over 120 days to analyze the therapeutic effects of TIPE-2 in tumor-bearing mice.

Immunohistochemistry. Immunohistochemical staining was performed according to the avidin-biotin-peroxidase technique. HCC tissues were isolated from experimental mice and paraffin-embedded tissue sections $(4 \mu \mathrm{m})$ were prepared and epitope retrieval was performed by heating the tissue sections at $100^{\circ} \mathrm{C}$ for $30 \mathrm{~min}$ in a citrate solution (10 mmol/1; pH 6.0) followed by dewaxing in xylene and rehydrating in a graded ethanol series for further analysis. Subsequently, paraffin-embedded sections were treated with hydrogen peroxide (3\%) for 10-15 min and were blocked in $5 \%$ bovine serum albumin (Sigma-Aldrich; Merck KGaA) for $10-15 \mathrm{~min}$ at $37^{\circ} \mathrm{C}$. Finally, the sections were incubated with biotinylated goat anti-mouse caspase-3 (1:1,000; cat. no. ab13847), caspase-9 (1:1,000; cat. no. ab32539), PI3K (1:1,000; cat. no. ab191606), AKT (1:1,000; cat. no. ab8805), GRP78 (1:1,000; cat. no. ab21685) and CHOP (1:1,000; cat. no. ab179823) antibodies (Abcam) at $4^{\circ} \mathrm{C}$ for $12 \mathrm{~h}$. Samples were washed three times with PBS and then incubated with HRP-conjugated goat anti-rabbit secondary antibody (1:2,000, cat. no. PV-6001; OriGene Technologies, Inc.) for $2 \mathrm{~h}$ at $37^{\circ} \mathrm{C}$. 3,3'-diaminobenzidene $(0.05 \%)$ was used as the chromogen for $30 \mathrm{~min}$ at $37^{\circ} \mathrm{C}$ and $1 \%$ hematoxylin as the nuclear counterstain for $30 \mathrm{~min}$ at $37^{\circ} \mathrm{C}$. The relative protein expression levels were analyzed using a chemiluminescence detection system (GE Healthcare). Tumor tissue images were captured with a ZEISS LSM 510 confocal microscope (magnification, $\mathrm{x} 40$; 
Zeiss AG, Oberkochen, Germany). Relative protein expression levels were determined using Quantity-One software 3.0 (Bio-Rad Laboratories, Inc.) and are presented as the $\mathrm{n}$-fold of $\beta$-actin expression levels.

Immunocytochemistry. HepG2 cells were treated with TIPE-2 $\left(2 \mathrm{mg} / \mathrm{ml}\right.$ ) for $12 \mathrm{~h}$ at $37^{\circ} \mathrm{C}$. Following this, cells were washed with PBS at room temperature and fixed with $4 \%$ paraformaldehyde for $1 \mathrm{~h}$ at $37^{\circ} \mathrm{C}$. The cells were washed again with PBS three times, blocked with $5 \%$ bovine serum albumin (Sigma-Aldrich; Merck KGaA) for $2 \mathrm{~h}$ at $37^{\circ} \mathrm{C}$ and subsequently stained with the following antibodies for $12 \mathrm{~h}$ at $4^{\circ} \mathrm{C}$ : Ki67 (1:1,000; cat. no. ab15580; Abcam), PCNA (1:1,000; cat. no. ab18197; Abcam), E-cadherin (1:1,000; cat. no. ab40772; Abcam) and fibronectin (1:1,000; cat. no. ab2413; Abcam). Cells were washed with PBS and subsequently incubated with an Oregon Green ${ }^{\circledR}$ 488-conjugated $\operatorname{IgG}(1: 1,000$; cat no. O-6382; Invitrogen; Thermo Fisher Scientific, Inc.) for $1 \mathrm{~h}$ in a light-protected chamber at $37^{\circ} \mathrm{C}$. Immunofluorescence signals were detected using a laser scanning confocal microscope (magnification, $\mathrm{x} 40$; Zeiss AG).

Statistical analysis. All data are presented as the mean \pm standard error of the mean of triplicate experiments. SPSS 19.0 software (IBM Corp., Armonk, NY, USA) was used for statistical analysis. Unpaired data were analyzed by Student's t-test. $\mathrm{P}<0.05$ was considered to indicate a statistically significant difference.

\section{Results}

Analysis of the inhibitory effects of TIPE-2 on HCC cell growth and proliferation in vitro. As shown in Fig. $1 \mathrm{~A}$ and B, TIPE-2 administration $(0.5,1,1.5,2.0$ and $2.5 \mathrm{mg} / \mathrm{ml})$ significantly inhibited HepG2 cell growth in a dose- and time-dependent manner. The results indicated that $2.0 \mathrm{mg} / \mathrm{ml}$ TIPE- 2 markedly suppressed HCC cell proliferation and increased the number of cells in S phase of the cell cycle (Fig. 1C and D). Western blot analysis demonstrated that TIPE-2 administration $(2.0 \mathrm{mg} / \mathrm{ml})$ decreased the expression levels of cyclin D1, CDK1 and CDK2 in HepG2 cells (Fig. 1E). Immunofluorescence indicated that TIPE-2 administration $(2.0 \mathrm{mg} / \mathrm{ml})$ decreased the expression levels of Ki67 and proliferating cell nuclear antigen in HepG2 cells (Fig. 1F). These results suggested that TIPE-2 may significantly inhibit HCC cell growth and proliferation in vitro.

Analysis of the inhibitory effects of TIPE-2 on HCC cell migration and invasion in vitro. Local migration and long-distance invasion are the most common characteristics of HCC. The present study investigated migration and invasion of HepG2 cells following treatment with TIPE-2 $(2.0 \mathrm{mg} / \mathrm{ml})$. Migration and invasion assays demonstrated that TIPE-2 significantly suppressed HepG2 cell migration and invasion in vitro (Fig. 2A and B). Western blot analysis demonstrated that TIPE-2 treatment decreased the expression levels of VIM, CT-I and Slug in HepG2 cells (Fig. 2C). In addition, TIPE-2 decreased JNK and NF- $\mathrm{kB}$ expression in HepG2 cells (Fig. 2D). Immunofluorescence demonstrated that E-cadherin/DNA and fibronectin/DNA expression levels were decreased in HepG2 cells following TIPE-2 treatment (Fig. 2E). HepG2 cell viability was also decreased by TIPE-2 treatment
(Fig. 2F). These results indicated that TIPE-2 may significantly inhibit migration and invasion of HepG2 cells via inhibiting the expression levels of cancer cell migration-associated proteins.

Analysis of the effects of TIPE-2 on HCC cell apoptosis in vitro. As shown in Fig. 3A, TIPE-2 administration $(2.0 \mathrm{mg} / \mathrm{ml})$ promoted apoptosis of HepG2 cells after $48 \mathrm{~h}$. Western blotting demonstrated that the expression levels of caspase- 3 and caspase- 8 were increased by TIPE-2 administration (Fig. 3B). In addition, TIPE- 2 administration downregulated P53 and Bcl-2 expression levels in HepG2 cells (Fig. 3C). Results also indicated that the expression and levels of eIF $2 \alpha$ and peIF $2 \alpha$ were upregulated in HepG2 cells following TIPE-2 treatment (Fig. 3D). Furthermore, the expression levels of NRF2 and BIP were increased in HepG2 cells following TIPE-2 treatment (Fig. 3E). The expression levels of GRP78 and CHOP were also increased in HepG2 cells following TIPE-2 treatment (Fig. 3F). These results suggested that TIPE-2 may promote HCC apoptosis in vitro.

TIPE-2 regulates $H C C$ cell apoptosis via regulation of the PI3K/AKT signaling pathway. As shown in Fig. 4A, the present study demonstrated that TIPE-2 significantly inhibited PI3K and AKT expression in HepG2 cells. In addition, N-ras and P27 expression were decreased by TIPE-2 treatment in HepG2 cells (Fig. 4B). pAKT levels were also decreased by TIPE-2 treatment in HepG2 cells when compared with pAKT levels in the control group (Fig. 4C). We observed that TIPE-2 decreased ratio of pAkt:Akt in HepG2 cells (Fig. 4D). As shown in Fig. 4E and F, pedue12.4-PI3K or pedue12.4-TIPE-2 upregulated PI3K and TIPE-2 mRNA expression, respectively, compared with pedue12.4-vector in HepG2 cells. Mechanistic analysis indicated that PI3K overexpression alone (PI3KOR) inhibited the apoptosis of HepG2 cells, whereas TIPE-2 treatment abolished this effect (Fig. 4G). In addition, N-ras and BIP expression was increased by PI3KOR in HepG2 cells (Fig. 4H). In addition, PI3KOR increased the expression levels of P53 and Bcl-2 in HepG2 cells when compared to the control group (Fig. 4I). These results suggested that TIPE-2 may regulate HCC cell apoptosis through regulation of the PI3K/AKT signaling pathway.

In vivo anticancer effects of TIPE-2 treatment on HepG2-bearing mice. The present study further investigated the antitumor effects of TIPE-2 treatment on HepG2-bearing nude mice. In order to avoid the interference of pathogenic microorganisms, SPF female BALB/c mice (body weight, 30-35 g) were implanted with HepG2 cells and treated with TIPE-2. As shown in Fig. 5A, TIPE-2 treatment $(6 \mathrm{mg} / \mathrm{kg})$ inhibited tumor growth during the 30-day observation period compared with in the control group. TUNEL assay demonstrated that TIPE-2 treatment increased the number of apoptotic cells in tumor tissues compared with in the PBS group (Fig. 5B). In addition, TIPE-2 treatment increased the expression levels of caspase-3 and caspase-8 (Fig. 5C), and upregulated PI3K and AKT in tumor tissues (Fig. 5D). Furthermore, TIPE-2 treatment increased GRP78 and CHOP expression in tumor tissues (Fig. 5E). Notably, survival of HepG2-bearing mice was prolonged by TIPE-2 treatment during the 120-day experiment (Fig. 5F). These results suggested that TIPE-2 may be a potential anticancer agent for the treatment of HCC. 
A

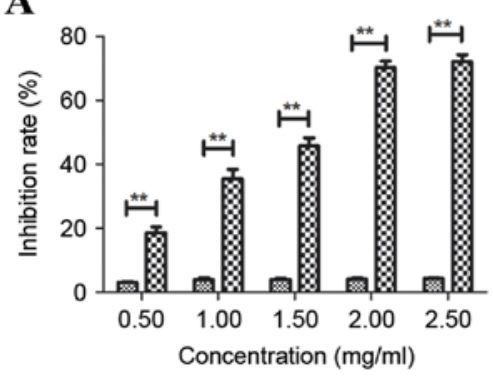

C

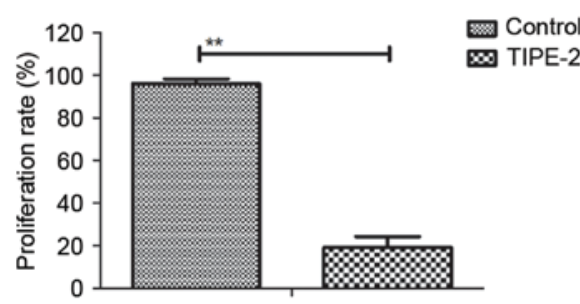

$\mathbf{E}$

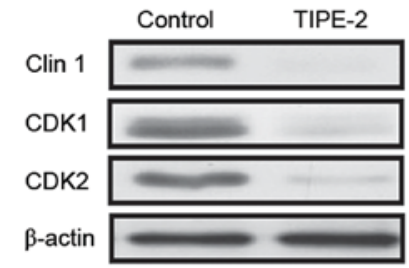

핐 Contro $\infty$ TIPE-2

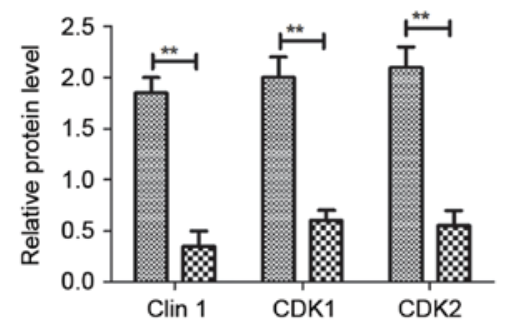

B

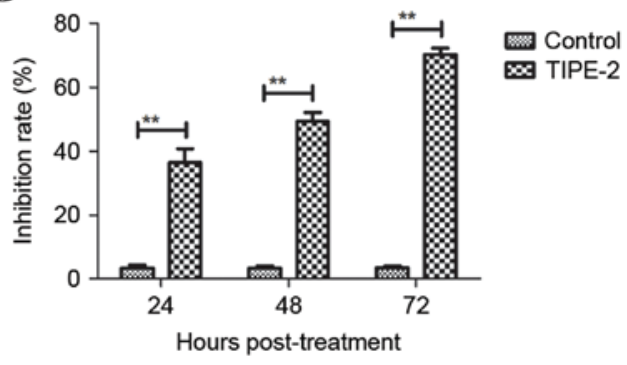

D

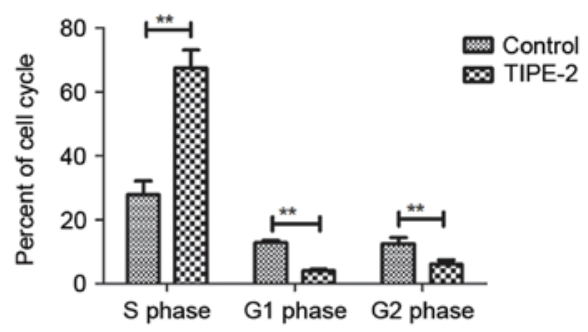

$\mathbf{F}$

Control
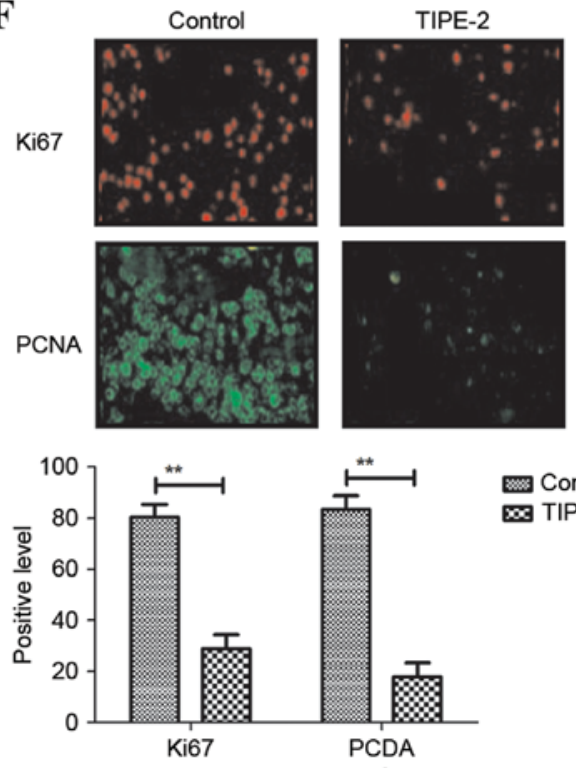

Figure 1. Inhibitory effects of TIPE-2 on HCC cell growth and proliferation in vitro. (A) TIPE-2 inhibited HepG2 cell growth in a dose- and (B) time-dependent manner. (C) TIPE-2 treatment suppressed HCC cell proliferation and (D) arrested HCC cells at S phase of the cell cycle. (E) Effects of TIPE-2 on the expression levels of cyclin D1 CDK1 and CDK2 in HepG2 cells. (F) Effects of TIPE-2 on the expression levels of Ki67 and PCNA in HepG2 cells, as determined by immunofluorescence. Magnification, $\mathrm{x} 40 .{ }^{* *} \mathrm{P}<0.01$ vs. control group. CDK1, cyclin-dependent kinase; HCC, hepatocellular carcinoma; PCNA, proliferating cell nuclear antigen; TIPE-2, tumor necrosis factor- $\alpha$-induced protein-8 like-2.

\section{Discussion}

Advanced stage HCC possesses aggressive potential for migration to adjacent and distant cells, and/or organs $(26,27)$. Clinical therapies are required that inhibit the migration and invasion of HCC cells, in order to prolong the survival of patients with $\operatorname{HCC}(28,29)$. It has previously been suggested that TIPE-2 serves an important role in tumorigenesis, and tumor growth, proliferation, aggressiveness and apoptosis. Although a previous study indicated the relevance of targeting the tumor suppressor gene TIPE-2, the molecular mechanism underlying TIPE-2-mediated apoptosis remains to be fully elucidated (30). The present study evaluated the inhibitory effects of TIPE- 2 on growth, aggressiveness and apoptosis of HCC cells in vitro, as well as the underlying mechanism of TIPE-2-mediated apoptosis of HepG2 cells. The results demonstrated that TIPE-2 administration significantly inhibited HCC cell growth, proliferation and aggressiveness. In addition, TIPE-2 administration promoted HCC cell apoptosis through regulation of the PI3K/AKT signaling pathway. Notably, the present findings suggested that TIPE-2 may be a potential anticancer agent for the treatment of HCC, as it was able to inhibit tumor growth and prolong survival. However, it must be noted that the HepG2 cell line is potentially misidentified, and may be derived from hepatoblastoma, rather than HCC (31). Therefore, the present study may identify the inhibitory effects of TIPE-2 on hepatic cancer cells in general, rather than on HCC cells specifically.

Induction of apoptosis and tumor cell death, thus resulting in the inhibition of growth and aggressiveness in patients, is the 
A
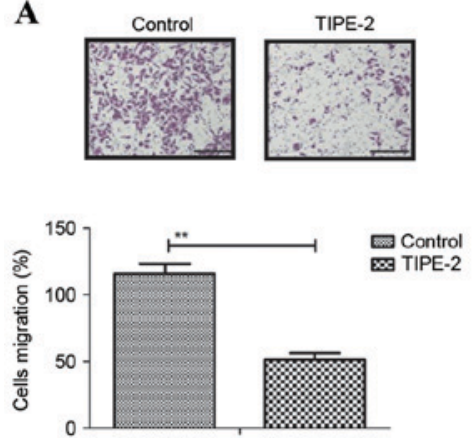

D
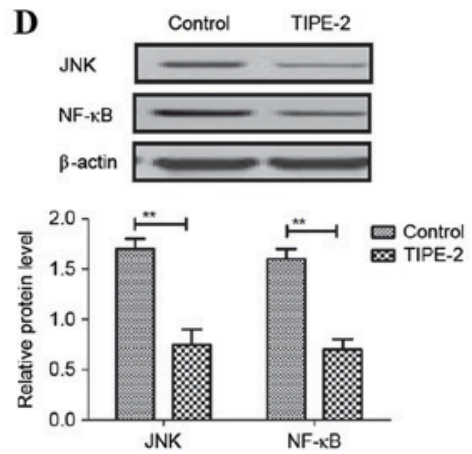

B
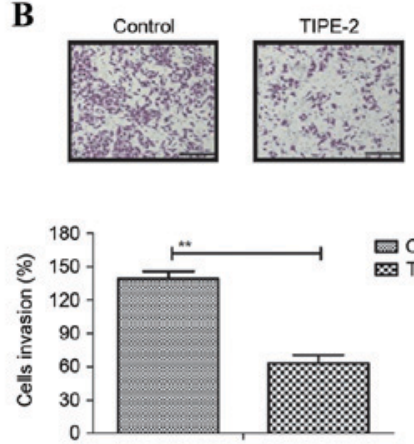

$\mathbf{E}$
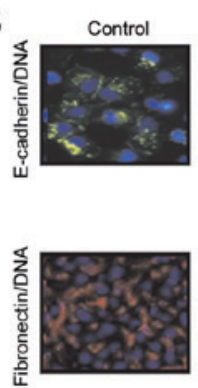

TIPE-2
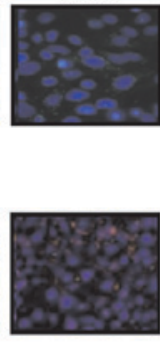

C
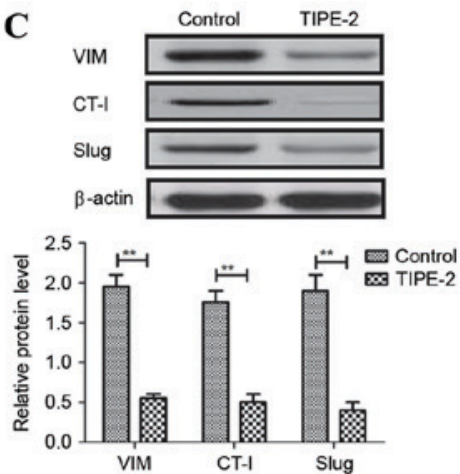

$\mathbf{F}$
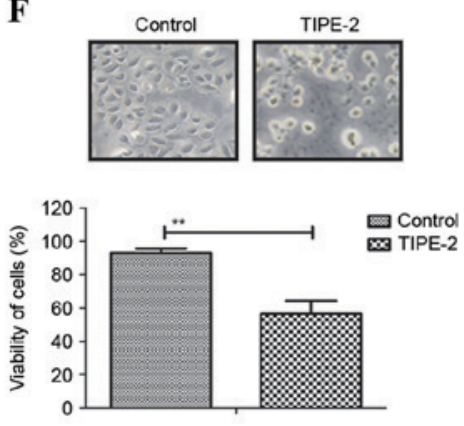

Figure 2. Inhibitory effects of TIPE-2 $(2.0 \mathrm{mg} / \mathrm{ml})$ on hepatocellular carcinoma cell migration and invasion in vitro. Effects of TIPE-2 on (A) migration and (B) invasion of HepG2 cells. Effects of TIPE-2 on the expression levels of (C) VIM, CT-I and Slug, and (D) JNK and NF- $\kappa$ B in HepG2 cells. (E) Immunofluorescence analysis of E-cadherin/DNA and fibronectin/DNA expression levels following TIPE-2 treatment in HepG2 cells. (F) Effects of TIPE-2 on viability of HepG2 cells. Magnification, $\mathrm{x} 40 .{ }^{* *} \mathrm{P}<0.01$ vs. control group. CT-I, collagen type I; JNK, c-Jun N-terminal kinase; NF- $\mathrm{B}$, nuclear factor- $\kappa \mathrm{B}$; TIPE-2, tumor necrosis factor- $\alpha$-induced protein-8 like-2; VIM, vimentin.

A
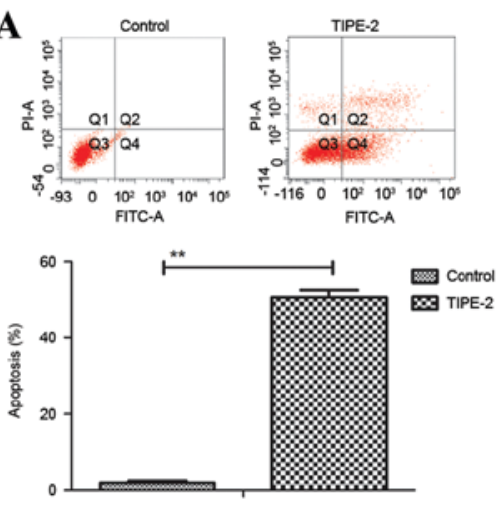

D
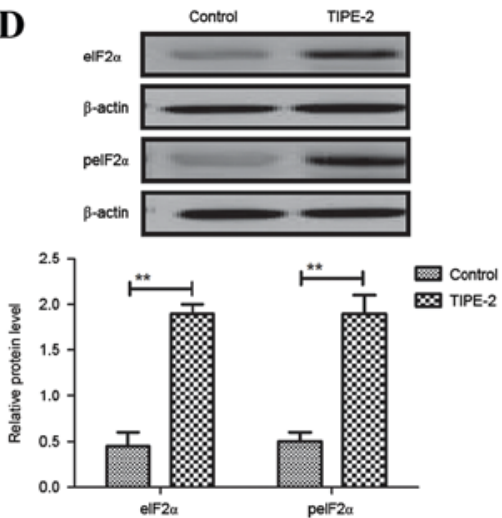

B
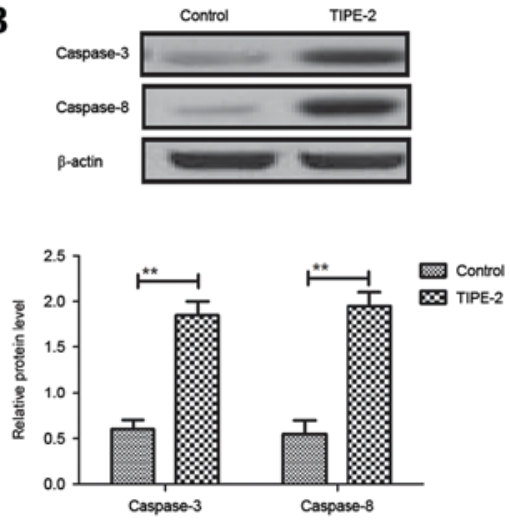

$\mathbf{E}$
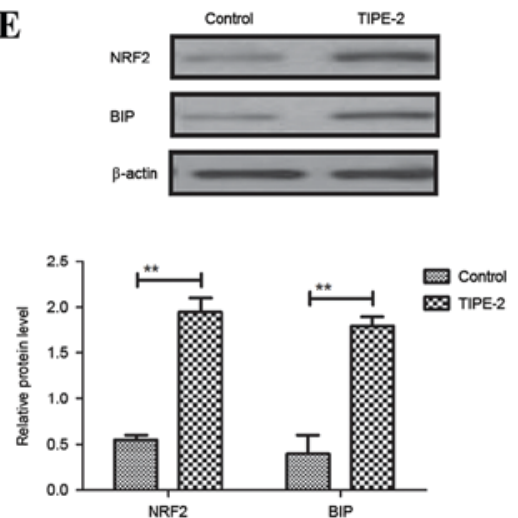

C
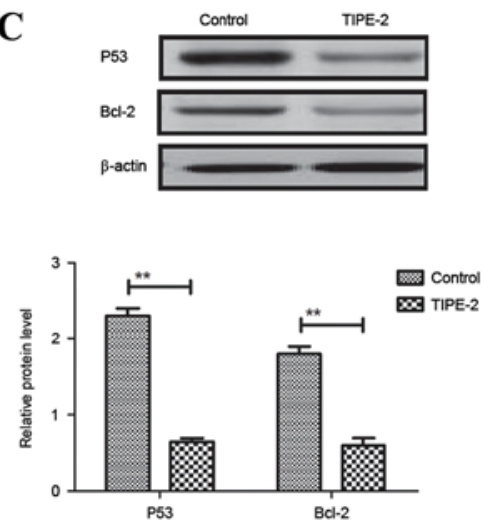

$\mathbf{F}$
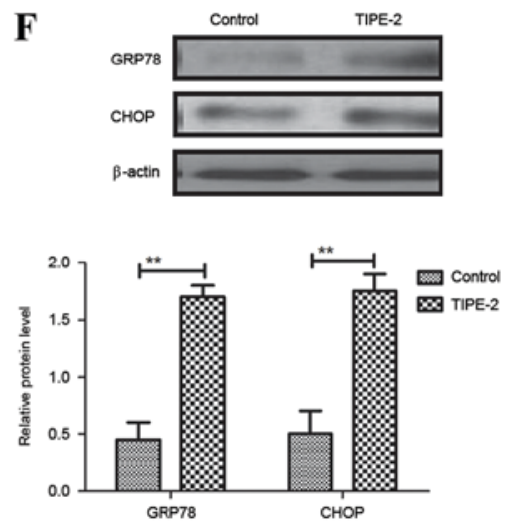

Figure 3. Effects of TIPE-2 (2.0 mg/ml) on hepatocellular carcinoma cell apoptosis in vitro. (A) Effects of TIPE-2 on apoptosis of HepG2 cells after 48 h, as determined by flow cytometry. Effects of TIPE- 2 treatment on the expression levels of (B) caspase-3 and caspase-8, (C) P53 and Bcl-2, (D) peIF2 $\alpha$ and eIF2 $\alpha$, (E) NRF2 and BIP, and (F) GRP78 and CHOP in HepG2 cells, as determined by western blotting. ** P<0.01 vs. control group. Bcl-2, B-cell lymphoma 2; BIP, binding immunoglobulin protein; CHOP, CCAAT-enhancer-binding protein homologous protein; eIF2 $\alpha$, eukaryotic initiation factor; FITC, fluorescein isothiocyanate; GRP78, glucose-regulated protein 78; peIF2 $\alpha$, phosphorylated-eIF2 $\alpha$; PI, propidium iodide; TIPE-2, tumor necrosis factor- $\alpha$-induced protein-8 like-2. 
A
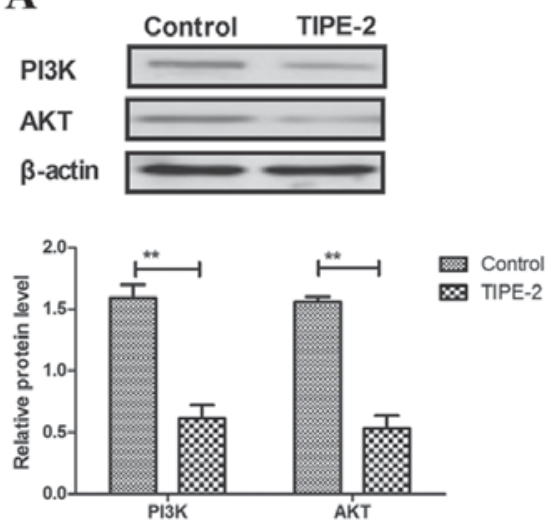

D

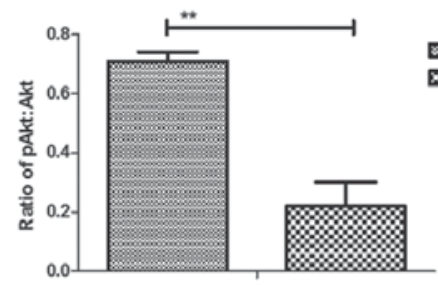

B
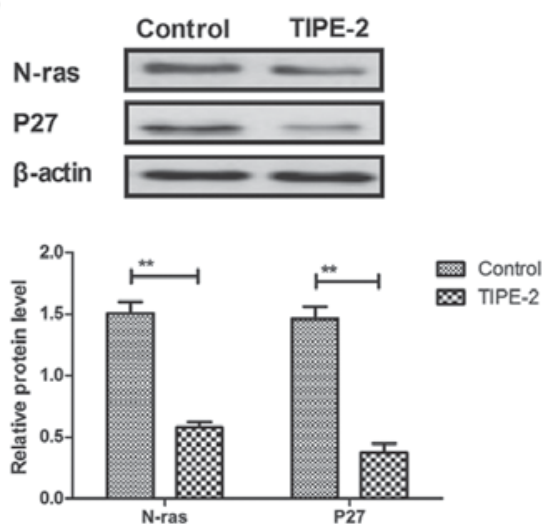

$\mathbf{E}$

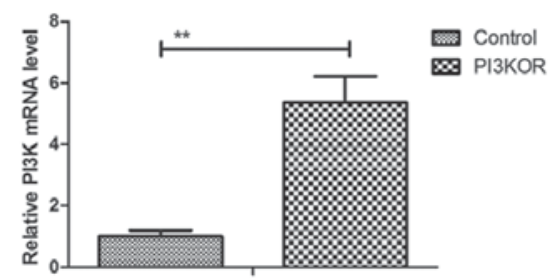

C
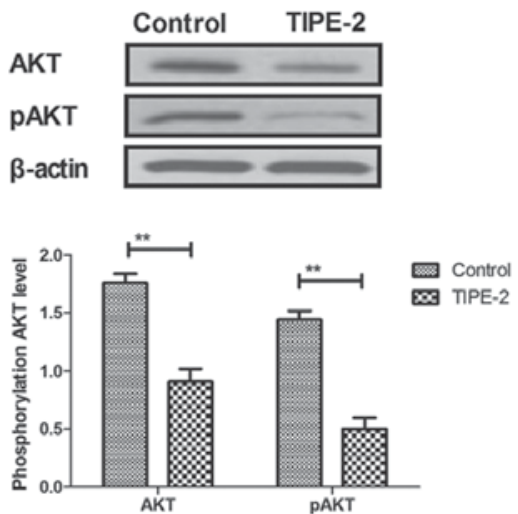

F

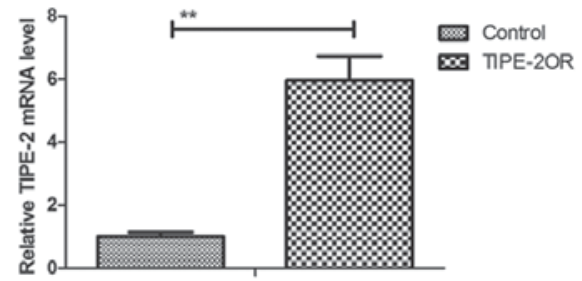

G

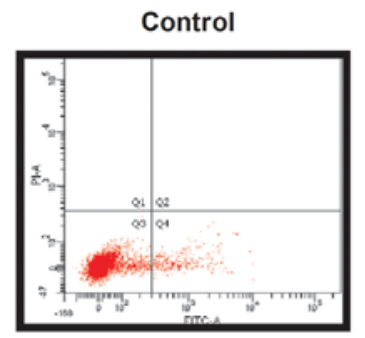

PI3KOR-TIPE-2
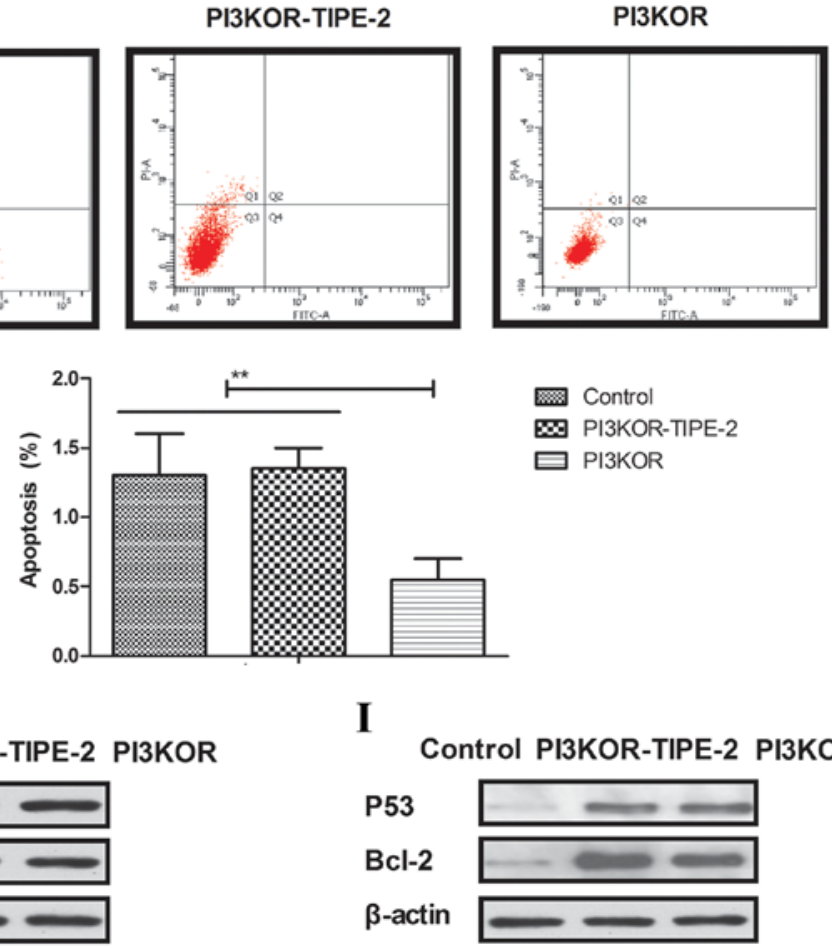

Control

$\infty$ PI3KOR-TIPE-2

$\square$ PI3KOR

H

Control PI3KOR-TIPE-2 PI3KOR
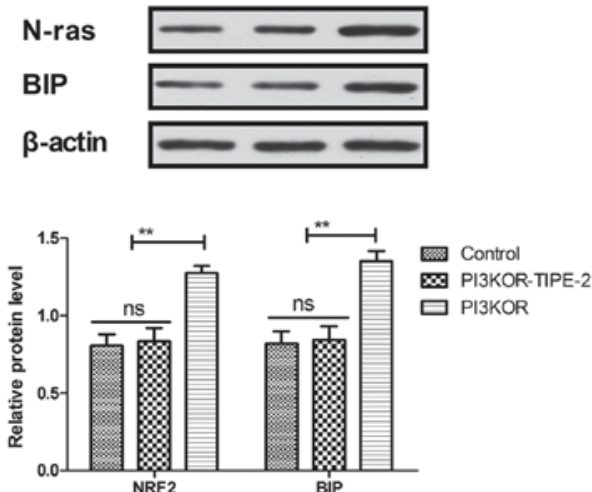

I

\section{Control PI3KOR-TIPE-2 PI3KOR}
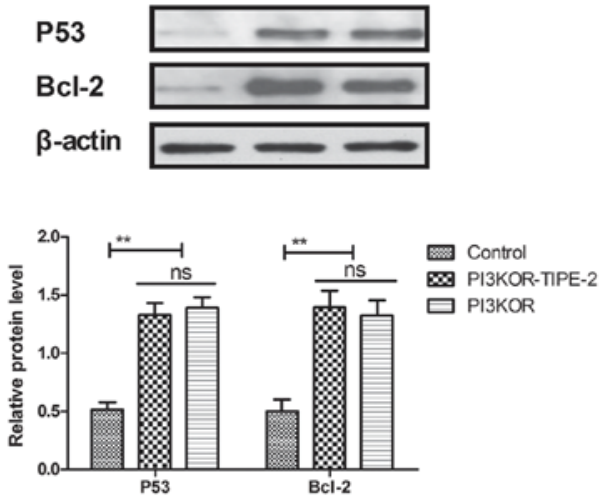

Figure 4. TIPE-2 regulates hepatocellular carcinoma cell apoptosis through regulation of the PI3K/AKT signaling pathway. Effects of TIPE-2 treatment on the expression levels of (A) PI3K and AKT, (B) N-ras and P27, and (C) pAKT in HepG2 cells. (D) TIPE-2 decreased the ratio of pAkt:Akt in HepG2 cells. Transfection with (E) pedue12.4-PI3K or (F) TIPE-2OR upregulates PI3K or TIPE-2 mRNA expression in HepG2 cells, respectively. ${ }^{* *} \mathrm{P}<0.01$ vs. control group. (G) PI3KOR prevented the apoptosis promoted by TIPE-2 treatment in HepG2 cells ** P<0.01, PI3KOR-TIPE-2 vs. PI3KOR or control group. Effects of PI3KOR on (H) N-ras and BIP, and (I) P53 and Bcl-2 expression in HepG2 cells. ${ }^{* *} \mathrm{P}<0.01$, PI3KOR-TIPE-2 or PI3KOR vs. control group. AKT, protein kinase B; Bcl-2, B-cell lymphoma 2; FITC, fluorescein isothiocyanate; N-ras, neuroblastoma Ras viral oncogene; OR, overexpression; pAKT, phosphorylated-AKT; PI, propidium iodide; PI3K, phosphoinositide 3-kinase; TIPE-2, tumor necrosis factor- $\alpha$-induced protein- 8 like- 2 . 
A

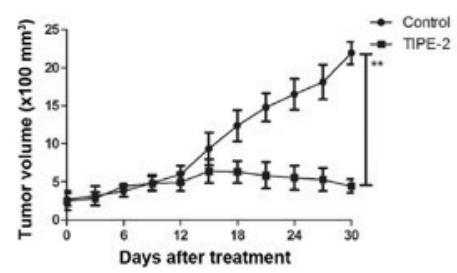

C
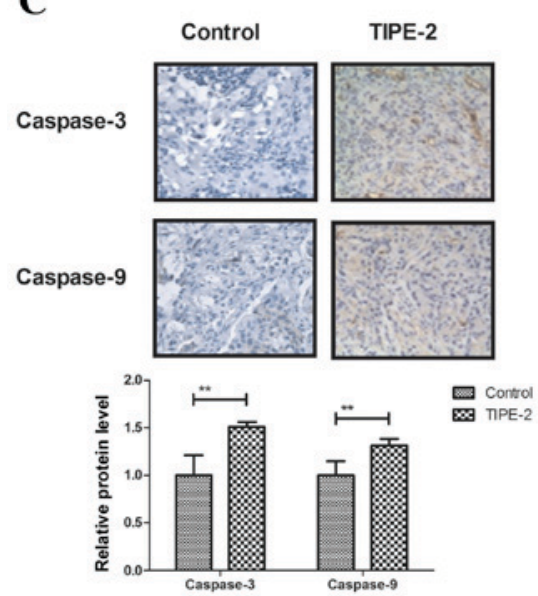

E

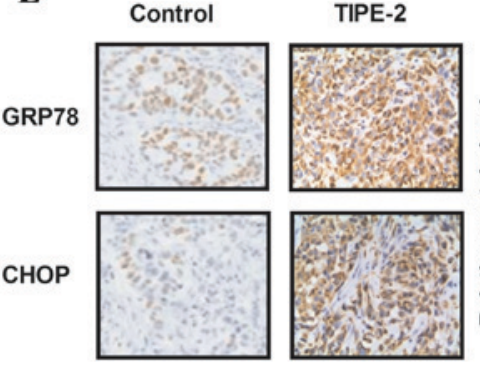

F

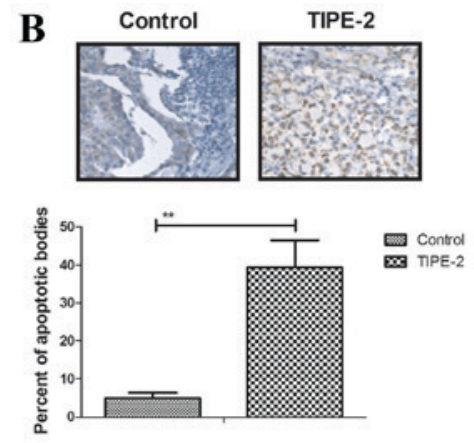

D

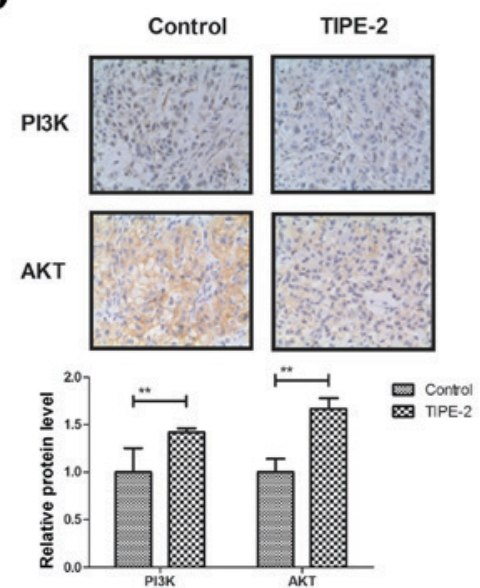

E TIPE-2
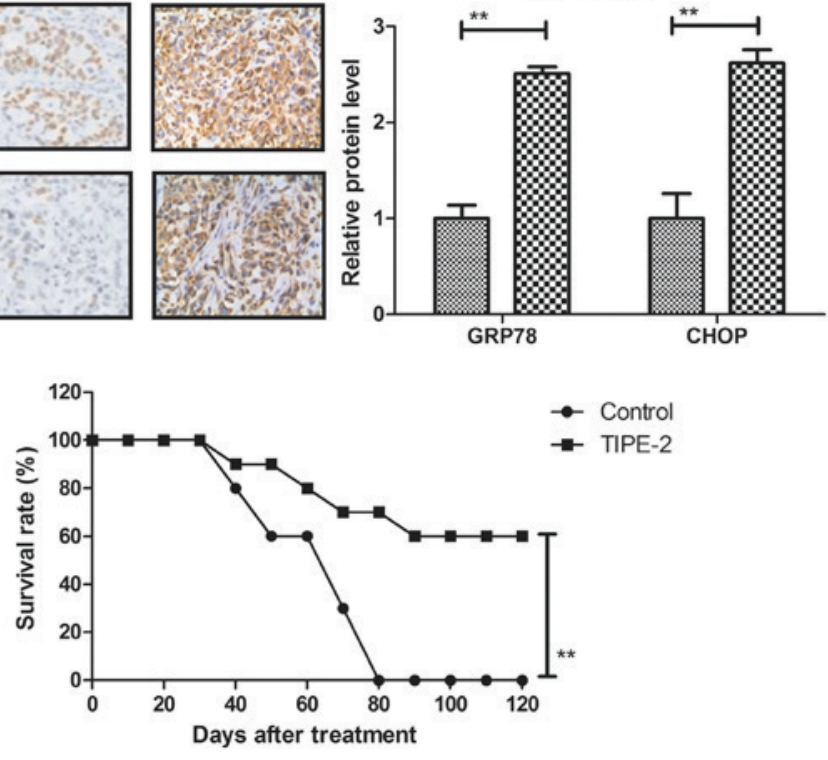

Figure 5. In vivo anticancer effects of TIPE-2 $(6.0 \mathrm{mg} / \mathrm{kg})$ treatment on hepatocellular carcinoma-bearing mice. (A) Antitumor effects of TIPE-2 treatment on HepG2-bearing nude mice. (B) TIPE-2 treatment promoted apoptosis of cells within tumor tissues. (C) TIPE-2 treatment increased the expression levels of caspase-3 and caspase-8 in tumor tissues. Effects of TIPE-2 treatment on the expression levels of (D) PI3K and AKT, and (E) GRP78 and CHOP in tumor tissues. Magnification, $\mathrm{x} 40$. (F) Survival rate of HepG2-bearing mice following treatment with TIPE-2 or PBS. ${ }^{* *} \mathrm{P}<0.01$ vs. control group. AKT, protein kinase B; CHOP, CCAAT-enhancer-binding protein homologous protein; GRP78, glucose-regulated protein 78; PI3K, phosphoinositide 3-kinase; TIPE-2, tumor necrosis factor- $\alpha$-induced protein- 8 like- 2 .

ultimate goal in neoplastic therapy (32). TIPE-2 is able to inhibit TLR4-mediated development of colon cancer via the downregulation of caspase- 8 activity. In the present study, TIPE-2 increased caspase- 8 expression in HCC cells, thus promoting apoptosis of HepG2 cells. A previous study demonstrated that TIPE-2 may inhibit TNF- $\alpha$-mediated HCC cell metastasis through the downregulation of extracellular signal-regulated kinase and the NF- $\mathrm{NB}$ signaling pathway (33). In addition, it has previously been indicated that regulation of P53-, Bcl-2and caspase-dependent signaling pathways in drug-induced apoptosis of HepG2 cells contributes to anti-proliferative effects (34). Notably, enhancement of P53 protein nuclear 
export may inhibit cisplatin-induced HepG2 cell apoptosis, which may hinder anticancer drug-induced HepG2 cell apoptosis (35). The present study demonstrated that TIPE-2 not only downregulated the expression of anti-apoptotic proteins (P53 and Bcl-2), but also indicated that TIPE-2 regulated apoptosis of HCC cells via the PI3K/AKT signaling pathway. In addition, another study revealed that bortezomib may arrest the proliferation of HepG2 HCC cells by increasing P27 (kip1) (36). Furthermore, Lin and Chiang (37) suggested that increasing P27 levels is conducive to anticancer drug-induced inhibition of human HCC HepG2 cells proliferation. The present data indicated that TIPE-2 treatment downregulated p27 expression, which may lead to inhibition of HepG2 cell proliferation.

Apoptosis induction and $\mathrm{G}_{2} / \mathrm{M}$ cell cycle arrest in human cancer cells via the Ras/Raf/mitogen-activated protein kinase and PI3K/AKT signaling pathways has been reported in previous studies $(38,39)$. The present results indicated that TIPE-2 decreased PI3K and AKT expression in HCC cells, which may have promoted apoptosis, and inhibited HepG2 cell growth and aggressiveness. Yue et al (40) reported that PI3K/AKT activation underlies human prostate cancer aggressiveness, and may be a target signaling pathway for human cancer therapy. The present findings indicated that TIPE-2 inhibited growth and aggressiveness of HCC cells through downregulation of the expression levels of VIM, CT-I and Slug. Notably, the present findings suggested that TIPE-2 promoted apoptosis in HCC in vitro and in vivo.

Endoplasmic reticulum stress is implicated in the progression of human carcinoma via the regulation of apoptotic signaling pathways in tumor cells (41). Edagawa et al (42) indicated that endoplasmic reticulum stress induced sensitization of P53-deficient human colon cancer cells to TNF-related apoptosis-inducing ligand-mediated apoptosis via the upregulation of death receptor 5, which may further lead to tumor growth inhibition. In the present study, the results demonstrated that TIPE-2 could promote HCC cell apoptosis through endoplasmic reticulum stress in vitro. Although research has indicated that TIPE-2 overexpression suppresses the proliferation, migration and invasion of prostate cancer cells by downregulation of the PI3K/AKT signaling pathway, to the best of our knowledge, TIPE-2-mediated apoptosis has been not reported in a previous study in HCC cells (43). In addition, TIPE-2 has been reported to suppress angiogenesis and invasiveness of non-small cell lung cancer via inhibiting Racl activation and vascular endothelial growth factor expression (44). The present study indicated that TIPE-2 treatment may regulate HCC cell apoptosis via regulation of the PI3K/AKT signaling pathway, which may result in activation of endoplasmic reticulum stress in HCC cells through promoting NRF2 and BIP expression (45).

In conclusion, the present study identified that TIPE-2 administration may efficiently inhibit HCC cell growth and aggressiveness via downregulation of the expression levels of VIM, CT-I and Slug. In addition, the results indicated that TIPE-2 administration promoted apoptosis of HCC cells through the PI3K/AKT signaling pathway, which may further contribute to the inhibition of tumor growth and may prolong survival of HepG2-bearing mice. These findings suggested that TIPE-2 may be a promising anticancer agent for the treatment of HCC.

\section{Acknowledgements}

The present study was supported by the Natural Science Foundation of Tianjin, China (grant no. 11JCYBJC28300), the Science and Technology Foundation of Tianjin Health Bureau (grant no. 2014KZ119), and the National Clinical Key Subject Construction Project of NHFPC Fund.

\section{References}

1. Menon KV, Hakeem AR and Heaton ND: Review article: Liver transplantation for hepatocellular carcinoma-a critical appraisal of the current worldwide listing criteria. Aliment Pharmacol Ther 40: 893-902, 2014.

2. Shariff MI, Cox IJ, Gomaa AI, Khan SA, Gedroyc W and Taylor-Robinson SD: Hepatocellular carcinoma: Current trends in worldwide epidemiology, risk factors, diagnosis and therapeutics. Expert Rev Gastroenterol Hepatol 3: 353-367, 2009.

3. Fung SK and Lok AS: Management of patients with hepatitis B virus-induced cirrhosis. J Hepatol 42 (Suppl): S54-S64, 2005

4. Chinnaratha MA, Chuang MY, Fraser RJ, Woodman RJ and Wigg AJ: Percutaneous thermal ablation for primary hepatocellular carcinoma: A systematic review and meta-analysis. J Gastroenterol Hepatol 31: 294-301, 2016.

5. Huang YH, Wu JC, Chen SC, Chen CH, Chiang JH, Huo TI, Lee PC, Chang FY and Lee SD: Survival benefit of transcatheter arterial chemoembolization in patients with hepatocellular carcinoma larger than $10 \mathrm{~cm}$ in diameter. Aliment Pharmacol Ther 23: 129-135, 2006.

6. Kim SS, Cho HJ, Lee HY, Park JH, Noh CK, Shin SJ, Lee KM, Yoo BM, Lee KJ, Cho SW and Cheong JY: Genetic polymorphisms in the Wnt/ $\beta$-catenin pathway genes as predictors of tumor development and survival in patients with hepatitis B virus-associated hepatocellular carcinoma. Clin Biochem 49: 792-801, 2016.

7. Dhir M, Melin AA, Douaiher J, Lin C, Zhen WK, Hussain SM, Geschwind JF, Doyle MB, Abou-Alfa GK and Are C: A review and update of treatment options and controversies in the management of hepatocellular carcinoma. Ann Surg 263: 1112-1125, 2016.

8. Simonetti RG, Cammà C, Fiorello F, Politi F, D'Amico G and Pagliaro L: Hepatocellular carcinoma. A worldwide problem and the major risk factors. Dig Dis Sci 36: 962-972, 1991.

9. Zidan A, Scheuerlein H, Schüle S, Settmacher U and Rauchfuss F: Epidemiological pattern of hepatitis $B$ and hepatitis $C$ as etiological agents for hepatocellular carcinoma in iran and worldwide. Hepat Mon 12: e6894, 2012.

10. Guo Z, Yu H, Liu C, Si T, Yang X, Zhang W, Xu Y and Li Y: Advances in endovascular therapy to treat primary hepatocellular carcinoma. Drug Discov Ther 9: 342-351, 2015.

11. Jiang J, Yu C, Chen M, Tian S and Sun C: Over-expression of TRIM37 promotes cell migration and metastasis in hepatocellular carcinoma by activating Wnt/beta-catenin signaling. Biochem Biophys Res Commun 464: 1120-1127, 2015.

12. Forner A, Reig M, Varela M, Burrel M, Feliu J, Briceño J, Sastre J, Martí-Bonmati L,LlovetJM,Bilbao JI, et al:Diagnosis and treatment of hepatocellular carcinoma. Update consensus document from the AEEH, SEOM, SERAM, SERVEI and SETH. Med Clin (Barc) 146: 511.e1-511.e22, 2016 (In Spanish).

13. Kim JH, Badawi M, Park JK, Jiang J, Mo X, Roberts LR and Schmittgen TD: Anti-invasion and anti-migration effects of miR-199a-3p in hepatocellular carcinoma are due in part to targeting CD151. Int J Oncol 49: 2037-2045, 2016.

14. Xu M, Liu Q, Jia Y, Tu K, Yao Y and Guo C: BCAT1 promotes tumor cell migration and invasion in hepatocellular carcinoma. Oncol Lett 12: 2648-2656, 2016.

15. Cheng XS, Sun SB, Zhong F, He K and Zhou J: Knockdown of histone methyltransferase hSETD1A inhibits progression, migration, and invasion in human hepatocellular carcinoma. Oncol Res 24: 239-245, 2016.

16. Xu L, Zhang M, Zheng X, Yi P, Lan C and Xu M: The circular RNA ciRS-7 (Cdrlas) acts as a risk factor of hepatic microvascular invasion in hepatocellular carcinoma. J Cancer Res Clin Oncol 143: 17-27, 2017.

17. Chen YJ, Chen CC and Huang HL: Induction of apoptosis by Armillaria mellea constituent armillarikin in human hepatocellular carcinoma. Onco Targets Ther 9: 4773-4783, 2016. 
18. Banjerdpongchai R, Wudtiwai B and Khawon P: Induction of human hepatocellular carcinoma HepG2 cell apoptosis by naringin. Asian Pac J Cancer Prev 17: 3289-3294, 2016.

19. Wang K, Ren Y, Liu Y, Zhang J and He JJ: Tumor necrosis factor $(\mathrm{TNF})-\alpha$-induced protein 8 -like-2 (TIPE2) inhibits proliferation and tumorigenesis in breast cancer cells. Oncol Res 25: 55-63, 2017.

20. Cao X, Zhang L, Shi Y, Sun Y, Dai S, Guo C, Zhu F, Wang Q, Wang J, Wang X, et al: Human tumor necrosis factor (TNF)-alphainduced protein 8-like 2 suppresses hepatocellular carcinoma metastasis through inhibiting Rac1. Mol Cancer 12: 149, 2013.

21. Li XM, Su JR, Yan SP, Cheng ZL, Yang TT and Zhu Q: A novel inflammatory regulator TIPE2 inhibits TLR4-mediated development of colon cancer via caspase-8. Cancer Biomark 14: 233-240, 2014.

22. Zhao Q, Zhao M, Dong T, Zhou C, Peng Y, Zhou X, Fan B, Ma W, Han M and Liu S: Tumor necrosis factor- $\alpha$-induced protein- 8 like-2 (TIPE2) upregulates p27 to decrease gastic cancer cell proliferation. J Cell Biochem 116: 1121-1129, 2015.

23. Ruan Q, Wang P, Wang T, Qi J, Wei M, Wang S, Fan T, Johnson D, Wan X, Shi W, et al: MicroRNA-21 regulates T-cell apoptosis by directly targeting the tumor suppressor gene Tipe2. Cell Death Dis 5: e1095, 2014.

24. Renshaw A and Elsheikh TM: A validation study of the Focalpoint GS imaging system for gynecologic cytology screening. Cancer Cytopathol 121: 737-738, 2013

25. Livak KJ and Schmittgen TD: Analysis of relative gene expression data using real-time quantitative PCR and the 2(-Delta Delta C(T)) method. Methods 25: 402-408, 2001

26. Poon RT, Fan ST, O'Suilleabhain CB and Wong J: Aggressive management of patients with extrahepatic and intrahepatic recurrences of hepatocellular carcinoma by combined resection and locoregional therapy. J Am Coll Surg 195: 311-318, 2002.

27. Au WY, Lie AK, Liang R, Liu CL, Shek TW and Lau GK: Aggressive hepatocellular carcinoma complicating pregnancy after autologous bone marrow transplantation for non-Hodgkin's lymphoma. Bone Marrow Transplant 29: 177-179, 2002.

28. Lubienski A, Bitsch RG, Schemmer P, Grenacher L, Dux M and Kauffmann GW: Long-term results of interventional treatment of large unresectable hepatocellular carcinoma (HCC): Significant survival benefit from combined transcatheter arterial chemoembolization (TACE) and percutaneous ethanol injection (PEI) compared to TACE monotherapy. Rofo 176: 1794-1802, 2004.

29. Yeh ML, Huang CI, Huang CF, Hsieh MY, Huang JF, Dai CY, Lin ZY, Chen SC, Yu ML and Chuang WL: Neoadjuvant transcatheter arterial chemoembolization does not provide survival benefit compared to curative therapy alone in single hepatocellular carcinoma. Kaohsiung J Med Sci 31: 77-82, 2015.

30. Liu QQ, Zhang FF, Wang F, Qiu JH, Luo CH, Zhu GY and Liu YF: TIPE2 inhibits lung cancer growth attributing to promotion of apoptosis by regulating some apoptotic molecules expression. PLoS One 10: e0126176, 2015.

31. López-Terrada D, Cheung SW, Finegold MJ and Knowles BB: Hep G2 is a hepatoblastoma-derived cell line. Hum Pathol 40 $1512-1515,2009$

32. Huang CS, Lee YR, Chen CS, Tu SH, Wang YJ, Lee $\mathrm{CH}$ Chen LC, Chang HW, Chang CH, Chih-Ming S, et al: Long-term ethanol exposure causes human liver cancer cells to become resistant to mitomycin $\mathrm{C}$ treatment through the inactivation of bad-mediated apoptosis. Mol Carcinog 49: 728-738, 2010

33. Zhang YH, Yan HQ, Wang F, Wang YY, Jiang YN, Wang YN and Gao FG: TIPE2 inhibits TNF- $\alpha$-induced hepatocellular carcinoma cell metastasis via Erk1/2 downregulation and NF- $\kappa \mathrm{B}$ activation. Int J Oncol 46: 254-264, 2015.
34. Handayani T, Sakinah S, Nallappan M and Pihie AH: Regulation of p53-, Bcl-2- and caspase-dependent signaling pathway in xanthorrhizol-induced apoptosis of HepG2 hepatoma cells. Anticancer Res 27: 965-971, 2007.

35. Zhang LJ, Li ZQ, Yang YP, Li XW and Ji JF: Tunicamycin suppresses cisplatin-induced HepG2 cell apoptosis via enhancing p53 protein nuclear export. Mol Cell Biochem 327: 171-182, 2009.

36. Baiz D, Pozzato G, Dapas B, Farra R, Scaggiante B, Grassi M, Uxa L, Giansante C, Zennaro C, Guarnieri G and Grassi G: Bortezomib arrests the proliferation of hepatocellular carcinoma cells HepG2 and JHH6 by differentially affecting E2F1, p21 and p27 levels. Biochimie 91: 373-382, 2009.

37. Lin YW and Chiang BH: 4-acetylantroquinonol B isolated from Antrodia cinnamomea arrests proliferation of human hepatocellular carcinoma HepG2 cell by affecting p53, p21 and p27 levels. J Agric Food Chem 59: 8625-8631, 2011.

38. Shin DY, Kim GY, Hwang HJ, Kim WJ and Choi YH: Diallyl trisulfide-induced apoptosis of bladder cancer cells is caspase-dependent and regulated by PI3K/Akt and JNK pathways. Environ Toxicol Pharmacol 37: 74-83, 2014.

39. Hatashita M, Taniguchi M, Baba K, Koshiba K, Sato T, Jujo Y, Suzuki R and Hayashi S: Sinodielide A exerts thermosensitizing effects and induces apoptosis and G2/M cell cycle arrest in DU145 human prostate cancer cells via the Ras/Raf/MAPK and PI3K/Akt signaling pathways. Int J Mol Med 33: 406-414, 2014.

40. Yue S, Li J, Lee SY, Lee HJ, Shao T, Song B, Cheng L, Masterson TA, Liu X, Ratliff TL and Cheng JX: Cholesteryl ester accumulation induced by PTEN loss and PI3K/AKT activation underlies human prostate cancer aggressiveness. Cell Metab 19: 393-406, 2014.

41. de Sà Bacelar T, da Silva AJ, Costa PR and Rumjanek VM: The pterocarpanquinone LQB 118 induces apoptosis in tumor cells through the intrinsic pathway and the endoplasmic reticulum stress pathway. Anticancer Drugs 24: 73-83, 2013.

42. Edagawa M, Kawauchi J, Hirata M, Goshima H, Inoue M, Okamoto T, Murakami A, Maehara Y and Kitajima S: Role of activating transcription factor 3 (ATF3) in endoplasmic reticulum (ER) stress-induced sensitization of p53-deficient human colon cancer cells to tumor necrosis factor(TNF)-relatedapoptosis-inducingligand(TRAIL)-mediated apoptosis through up-regulation of death receptor 5 (DR5) by zerumbone and celecoxib. J Biol Chem 289: 21544-21561, 2014.

43. Lu Q, Liu Z, Li Z, Chen J, Liao Z, Wu WR and Li YW: TIPE2 overexpression suppresses the proliferation, migration and invasion in prostate cancer cells by inhibiting PI3K/Akt signaling pathway. Oncol Res 24: 305-313, 2016.

44. Li Z, Guo C, Liu X, Zhou C, Zhu F, Wang X, Wang Q, Shi Y, Wang J, Zhao W and Zhang L: TIPE2 suppresses angiogenesis and non-small cell lung cancer (NSCLC) invasiveness via inhibiting Rac1 activation and VEGF expression. Oncotarget 7: 62224-62239, 2016.

45. Tang J, Guo YS, Zhang Y, Yu XL, Li L, Huang W, Li Y, Chen B, Jiang JL and Chen ZN: CD147 induces UPR to inhibit apoptosis and chemosensitivity by increasing the transcription of Bip in hepatocellular carcinoma. Cell Death Differ 19: 1779-1790, 2012.

This work is licensed under a Creative Commons Attribution-NonCommercial-NoDerivatives 4.0 International (CC BY-NC-ND 4.0) License. 